\title{
THE CHOICE OF SKIN AREA FOR TOXIN ASSAY
}

\author{
BY ROBERT L. BERG 1 \\ (From the Virus Institution of the Royal Caroline Institute, and the State Bacteriological \\ Laboratory, Stockholm)
}

(Submitted for publication December 16, 1953; accepted June 25, 1954)

A number of toxins have been assayed by measurement of lesions produced in small animals after intradermal injection of the toxin. The skin areas injected have been chosen largely for ease of injection, but incomplete studies have been made of which areas are most sensitive and which give the least variable responses. In the present paper the relative sensitivity and variability of different skin areas have been determined when intradermal hemorrhages are produced in the guinea pig by injection of Witte's peptone.

\section{METHODS}

Seven young guinea pigs (200 to $250 \mathrm{gm}$.) were depilated by shaving or with depilatory powder shortly before use. The skin of the abdomen, back, and flanks was marked off in squares with India Ink. Witte's peptone, dissolved in saline, was then injected in three concentrations in $1 / 16 \mathrm{cc}$. volume according to Figure 1. This pattern represents an endless series of Latin Squares of the same design. Two hours after injection the diameters of the resulting intradermal hemorrhages were measured immediately after exsanguination. The lesions were usually sharply demarcated. In four of these animals trypan blue was injected intravenously before skin injections were made, and the diameter of the discolored area also measured.

A classical Latin Square analysis was carried out for each animal according to Fisher (1). Rows I, II, and III (Figure 1) produce three Latin Squares which overlap with the three squares produced by rows II, III, and IV; and each set of three squares was treated with a combined analysis of the three squares. The two sets of data share two-thirds of the raw data in common. It is not possible to combine these two sets of data into a single analysis inasmuch as the Latin Square design is a three by three design and cannot accommodate a fourth row. The two sets of data are, therefore, not independent of each other and it is to be expected that the results would agree closely. Neither was it feasible to plan larger Latin Squares, as only incomplete squares would have been left for a revised analysis after eliminating the vari-

1 Formerly (1948-49) Moseley Travelling Fellow. Present address: Departments of Medicine, Harvard Medical School and Massachusetts General Hospital, Boston, Mass. able areas. In view of the homogeneity of the results of these individual animal analyses, a combined analysis for the seven animals was carried out (2). In these analyses the square root of the diameter, expressed in millimeters, was used as explained elsewhere (3).

\section{RESULTS}

The results are tabulated in Table $I$, which is laid out in the same way as Figure 1, and each square corresponds to a single square in Figure 1. The sum of the responses of all seven guinea pigs in each location is indicated in the individual values for each square.

The analysis in Table II indicates a sizeable error due to a column-square interaction (i.e., individual column differences vary from square to square.) By inspection of the raw data in Table $I$, it is clear that the two columns representing the ventral area are the source of the variability. However, this variability does not appear in the statistical analysis as a "between columns" effect inasmuch as the "between columns" effect is made up of the sum of Columns A, D, and G compared with Columns B, E, H, and Columns $\mathrm{C}, \mathrm{F}$, and $\mathrm{I}$; thus, the significantly variable areas in the abdominal region, namely Columns $A$ and $I$ are submerged in other relatively non-variable values. In the same way the "between row" variation will not disclose any unusual variation because values from Column $A$ and $I$ are equally distributed in each of the rows; however, the discrepancy due to the abdominal variation is evident in that portion of the analysis in which the effect of individual column totals is considered, and that is in the "column square" interaction of this analysis. Most lesions in the ventral area are much smaller than those on the back, and there is considerable variability. When the analysis is carried out (Table III) omitting the ventral skin and the single column in the middle of the back (the latter for convenience only) the resulting values show no significant variation due to position. 


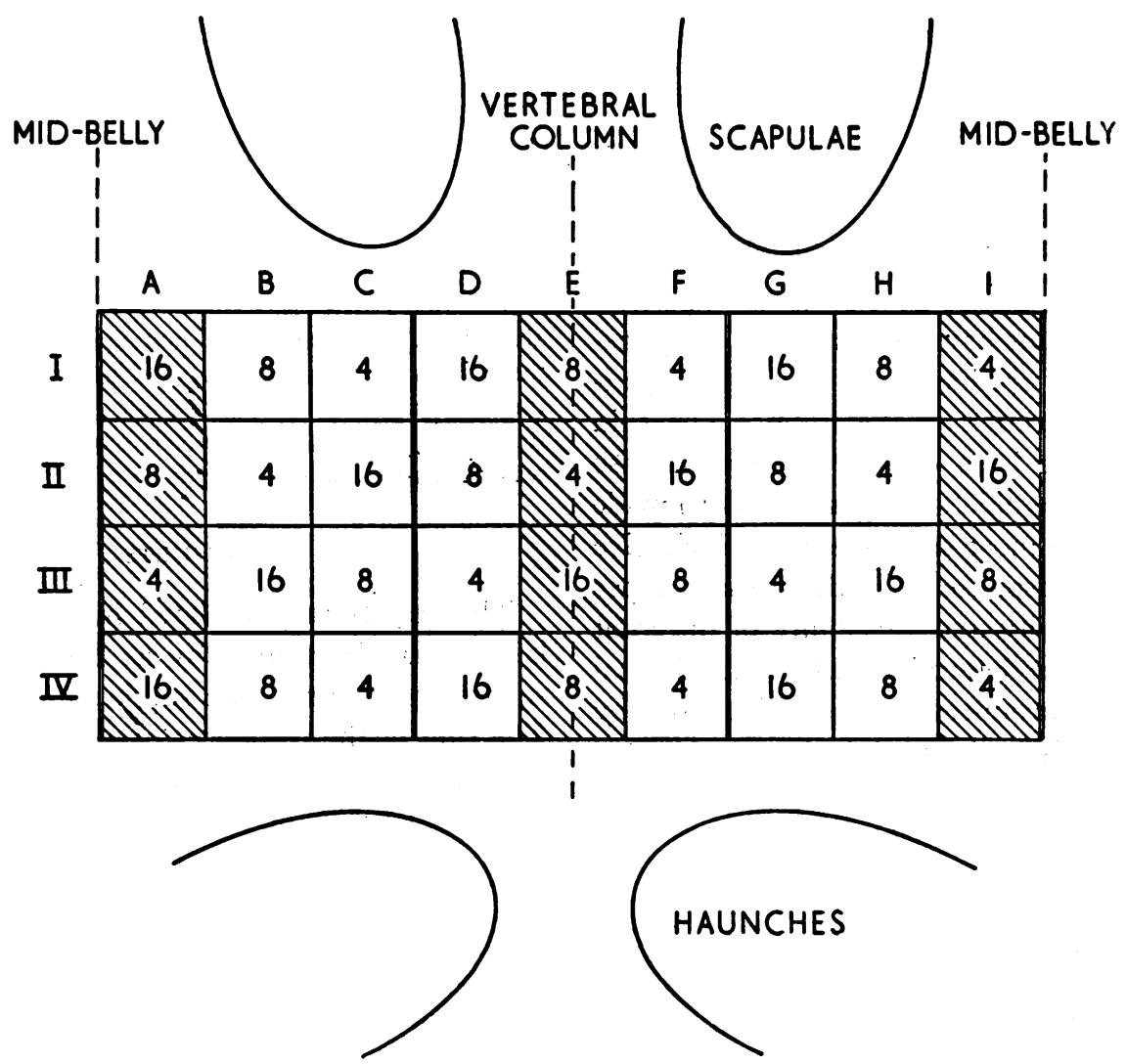

Fig. 1. Schematic Representation of the Skin of a Guinea Pig Including the AREAS USED FOR INJECTION

The numerals refer to the concentration of peptone injected in $\mathrm{mg}$. per $\mathrm{ml}$. of peptone nitrogen. The groups' of 12 squares set off by double lines represent three sets of two overlapping Latin Squares used in the analysis (e.g., A, B, C-I, II, III, and A, B, C-II, III, IV). The cross-hatched squares represent the areas discarded in final use of the test.

TABLE I

The tolal diameters of skin hemorrhages produced by peptone in seven guinea pigs injected intradermally according to Figure $1^{*}$

\begin{tabular}{ccccccccccc}
\hline & $\mathrm{A}$ & $\mathrm{B}$ & $\mathrm{C}$ & $\mathrm{D}$ & $\mathrm{E}$ & $\mathrm{F}$ & $\mathrm{G}$ & $\mathrm{H}$ & $\mathrm{I}$ & \\
\hline $\begin{array}{c}\text { Totals for } \\
\text { columns }\end{array}$ & 29 & 60 & 75 & 49 & 57 & 62 & 50 & 66 & 36 & 484 \\
I, II, III & 15.03 & 25.71 & 35.71 & 23.48 & 25.64 & 30.70 & 25.46 & 27.95 & 16.51 & 226.19 \\
I & 25 & 13 & 7 & 37 & 17 & 8 & 36 & 13 & 13 & 159 \\
& 11.62 & 7.69 & 5.83 & 15.92 & 8.18 & 5.66 & 15.75 & 7.15 & 5.06 & 82.86 \\
II & 2 & 0 & 48 & 12 & 2 & 40 & 9 & 2 & 21 & 136 \\
& 2.00 & 0 & 18.02 & 11.63 & 7.56 & 16.70 & 5.97 & 2.00 & 10.03 & 63.94 \\
III & 2 & 47 & 20 & 0 & 38 & 14 & 5 & 51 & 2 & 179 \\
& 1.41 & 18.02 & 11.63 & 0 & 16.04 & 8.34 & 3.73 & 18.81 & 1.41 & 79.40 \\
IV & 25 & 9 & 4 & 44 & 11 & 6 & 43 & 21 & 5 & 168 \\
& 11.96 & 4.86 & 3.41 & 17.37 & 5.70 & 4.15 & 17.29 & 11.11 & 3.15 & 79.01 \\
Totals for & 29 & 56 & 72 & 56 & 51 & 60 & 57 & 74 & 28 & 483 \\
columns & 15.38 & 22.88 & 33.29 & 24.93 & 23.16 & 29.19 & 26.99 & 31.92 & 14.59 & 222.34 \\
II, III, IV & & & & & & & & & \\
\hline
\end{tabular}

* The upper values are arithmetic totals; the lower values in italics are totals of the square roots of the raw values. 
TABLE II

The analysis of the Latin Squares when all columns are included $\dagger$

\begin{tabular}{|c|c|c|c|c|c|}
\hline & Rows & $\begin{array}{c}\text { Degrees of } \\
\text { freedom }\end{array}$ & $\underset{\text { Squares of }}{\text { Squ }}$ & $\begin{array}{l}\text { Mean } \\
\text { square }\end{array}$ & Ratio \\
\hline Rows & $\begin{array}{l}\text { I, II, III } \\
\text { II, III, IV }\end{array}$ & 2 & $\begin{array}{l}22.56 \\
17.27\end{array}$ & $\begin{array}{r}11.28 \\
8.64\end{array}$ & $\begin{array}{l}2.47 \\
1.97\end{array}$ \\
\hline Columns & $\begin{array}{l}\text { I, II, III } \\
\text { II, III, IV }\end{array}$ & 2 & $\begin{array}{r}22.48 \\
7.77\end{array}$ & $\begin{array}{r}11.24 \\
3.88\end{array}$ & $\begin{array}{l}2.46 \\
1.13\end{array}$ \\
\hline Treatments & $\begin{array}{l}\text { I, II, III } \\
\text { II, III, IV }\end{array}$ & 2 & $\begin{array}{l}787.85 \\
911.09\end{array}$ & $\begin{array}{l}393.92 \\
455.54\end{array}$ & $\begin{array}{r}86.34^{* * *} \\
103.69^{* * *}\end{array}$ \\
\hline Squares & $\begin{array}{l}\text { I, II, III } \\
\text { II, III, IV }\end{array}$ & 2 & $\begin{array}{l}5.64 \\
1.88\end{array}$ & $\begin{array}{r}2.82 \\
.94\end{array}$ & $\frac{1.62}{4.66}$ \\
\hline $\begin{array}{l}\text { Row-square } \\
\text { interaction }\end{array}$ & $\begin{array}{l}\text { I, II, III } \\
\text { II, III, IV }\end{array}$ & 4 & $\begin{array}{l}18.93 \\
40.76\end{array}$ & $\begin{array}{r}4.73 \\
10.19\end{array}$ & $\begin{array}{l}1.00 \\
4.16\end{array}$ \\
\hline $\begin{array}{l}\text { Column-square } \\
\text { interaction }\end{array}$ & $\begin{array}{l}\text { I, II, III } \\
\text { II, III, IV }\end{array}$ & 4 & $\begin{array}{r}82.08 \\
105.78\end{array}$ & $\begin{array}{l}20.52 \\
26.44\end{array}$ & $\begin{array}{c}4.50^{*} \\
10.79^{* *}\end{array}$ \\
\hline $\begin{array}{l}\text { Treatment-square } \\
\text { interaction }\end{array}$ & $\begin{array}{l}\text { I, II, III } \\
\text { II, III, IV }\end{array}$ & 4 & $\begin{array}{r}16.54 \\
6.03\end{array}$ & $\begin{array}{l}4.14 \\
1.51\end{array}$ & $\frac{1.14}{1.63}$ \\
\hline Error & $\begin{array}{l}\text { I, II, III } \\
\text { II, III, IV }\end{array}$ & 6 & $\begin{array}{l}28.40 \\
14.71\end{array}$ & $\begin{array}{l}4.73 \\
2.45\end{array}$ & \\
\hline Total & $\begin{array}{l}\text { I, II, III } \\
\text { II, III, IV }\end{array}$ & 26 & $\begin{array}{r}984.49 \\
1,105.30\end{array}$ & & \\
\hline Combined error & $\begin{array}{l}\text { I, II, III } \\
\text { II, III, IV }\end{array}$ & 14 & $\begin{array}{l}63.87 \\
61.51\end{array}$ & $\begin{array}{l}4.56 \\
4.39\end{array}$ & \\
\hline
\end{tabular}

† Rows I, II, III were divided into three Latin Squares ABC, DEF, and GHI. Levels of significance are indicated in the column labelled "Ratio."

* Indicates a p value of less than 0.05 .

** Indicates a value of less than 0.01 .

*** Indicates a value of less than 0.001 .

The underlined values are inverse ratios.

The accuracy obtained in assay procedures is conveniently expressed as the standard error of potency $\left(S_{M}\right)(4)$. An analysis of variance of the results from the seven animals indicates that in a single animal the $S_{M}$ for an assay using thirtysix injections in all the areas indicated in Figure 1 would be approximately .25 , and after conversion to arithmetic units would be .56. The $\mathrm{S}_{\mathbf{M}}$ of the eight ventral areas above would be .67 and after conversion 1.79. The $\mathrm{S}_{\mathbf{M}}$ of the 28 back areas above would be .22 and after conversion .48 , so that with fewer injections (omitting the ventral area) greater accuracy is achieved.

The area of the blue discoloration in the four animals treated with dye was also smaller in the ventral area, but not significantly so.

\section{DISCUSSION}

The assay of dermatonecrotic and erythrogenic bacterial toxins is customarily carried out in the back, flank, or ventral skin of rabbits or guinea pigs; the choice apparently dictated by ease of injection or tradition $(5,6)$. Wadley $(7)$ has reported that different areas of cow hide have different sensitivity to tuberculin. Differing sensitivities to histamine and allergens in various human skin areas have been observed by Swain and Becker (8) and they have reviewed previous similar studies in humans. The toxins arising from proteolytic processes have also been tested in the skin of these animals. Menkin (9) and others (10-16) injected preparations of leukotaxine, enzymes, venoms, or other irritants into the ventral skin or back (17) of rabbits and measured grossly the size of the blue spots due to the escape of intravenously injected dye into these areas.

Miles and Miles (18) used a Latin Square design on the dorsal skin of guinea pigs to show lack of important variability in that area in responses to histamine, histamine-liberator, and leukotaxine with the dye technique. They reported larger lesions in the thinner ventral skin, which is in con- 
TABLE III

The analysis of the Latin Squares when only columns BCD and FGH are included, thus eliminating the belly and the mid-line of the back $f$

\begin{tabular}{|c|c|c|c|c|c|}
\hline & Rows & $\begin{array}{l}\text { Degrees of } \\
\text { freedom }\end{array}$ & $\begin{array}{l}\text { Sum of } \\
\text { squares }\end{array}$ & $\begin{array}{l}\text { Mean } \\
\text { square }\end{array}$ & Ratio \\
\hline Rows & $\begin{array}{l}\text { I, II, III } \\
\text { II, III, IV }\end{array}$ & 2 & $\begin{array}{l}9.07 \\
9.19\end{array}$ & $\begin{array}{l}4.54 \\
4.59\end{array}$ & $\frac{1.03}{1.17}$ \\
\hline Columns & $\begin{array}{l}\text { I, II, III } \\
\text { II, III, IV }\end{array}$ & 2 & $\begin{array}{l}7.89 \\
5.67\end{array}$ & $\begin{array}{l}3.94 \\
2.84\end{array}$ & $\frac{1.12}{1.39}$ \\
\hline Treatments & $\begin{array}{l}\text { I, II, III } \\
\text { II, III, IV }\end{array}$ & 2 & $\begin{array}{l}635.72 \\
735.04\end{array}$ & $\begin{array}{l}317.86 \\
367.52\end{array}$ & $\begin{array}{l}71.92^{* * *} \\
93.35^{* * *}\end{array}$ \\
\hline Squares & $\begin{array}{l}\text { I, II, III } \\
\text { II, III, IV }\end{array}$ & 1 & $\begin{array}{r}.04 \\
2.72\end{array}$ & $\begin{array}{r}.04 \\
2.72\end{array}$ & $\frac{126.27}{1.45}$ \\
\hline $\begin{array}{l}\text { Row-square } \\
\text { interaction }\end{array}$ & $\begin{array}{l}\text { I, II, III } \\
\text { II, III, IV }\end{array}$ & 2 & $\begin{array}{r}.57 \\
5.68\end{array}$ & $\begin{array}{r}.28 \\
2.84\end{array}$ & $\frac{7.49}{1.10}$ \\
\hline $\begin{array}{l}\text { Column-square } \\
\text { interaction }\end{array}$ & $\begin{array}{l}\text { I, II, III } \\
\text { II, III, IV }\end{array}$ & 2 & $\begin{array}{l}24.96 \\
18.67\end{array}$ & $\begin{array}{r}12.48 \\
9.33\end{array}$ & $\begin{array}{l}5.86 \\
3.61\end{array}$ \\
\hline $\begin{array}{l}\text { Treatment-square } \\
\text { interaction }\end{array}$ & $\begin{array}{l}\text { I, II, III } \\
\text { II, III, IV }\end{array}$ & 2 & $\begin{array}{r}10.15 \\
4.69\end{array}$ & $\begin{array}{l}5.08 \\
2.34\end{array}$ & $\begin{array}{l}2.38 \\
1.10\end{array}$ \\
\hline Error & $\begin{array}{l}\text { I, II, III } \\
\text { II, III, IV }\end{array}$ & 4 & $\begin{array}{r}8.51 \\
10.34\end{array}$ & $\begin{array}{l}2.13 \\
2.58\end{array}$ & \\
\hline Total & $\begin{array}{l}\text { I, II, III } \\
\text { II, III, IV }\end{array}$ & 17 & $\begin{array}{l}696.91 \\
791.99\end{array}$ & & \\
\hline Combined error & $\begin{array}{l}\text { I, II, III } \\
\text { II, III, IV }\end{array}$ & 10 & $\begin{array}{l}44.20 \\
39.37\end{array}$ & $\begin{array}{l}4.42 \\
3.94\end{array}$ & \\
\hline
\end{tabular}

$\dagger$ There is now no significant column effect in the Column-square interaction.

*** Indicates a value of less than 0.001 .

trast to the findings of the present experiments. Moore and Tobin (19) mapped skin areas in which radioactive dyes preferentially accumulated as a result of inflammation, but no systematic analysis of all trunk areas has previously been reported.

The Latin Square analysis is especially well suited for determining spatial variability. Originally designed for agricultural field experiments (1), it offers a simple and expedient means of determining which skin areas are least variable and most sensitive for skin assay.

An analysis similar to this might be performed for any given toxin, though it is not unlikely that the back of guinea pigs may prove the least variable area in its responses to a wide range of proteolytic products and bacterial toxins.

\section{SUMMARY}

1. Witte's peptone produces hemorrhagic lesions in the skin of guinea pigs when injected intradermally.
2. By means of a Latin Square analysis of skin area, it has been found that the back shows no significant variability in its response, whereas the ventral skin is less sensitive than the back and, if included, contributes considerable variability and lack of precision.

3. Greater accuracy may be obtained in the skin assay of toxins if a Latin Square analysis be performed for the particular animal and toxin concerned.

\section{ACKNOWLEDGMENTS}

Th author is indebted to Dr. William Reynolds of the Harvard School of Public Health for help with the statistical analysis.

\section{REFERENCES}

1. Fisher, R. A., Statistical Methods for Research Workers. Ed. 11, Edinburgh, Oliver \& Boyd, 1950, 354 p.

2. Cochran, W. G., and Cox, G. M., Experimental Designs. New York, John Wiley \& Sons, Inc., 1950, 454 p. 
3. Berg, R. L., and Field, R. A., The preparation and assay of toxic proteolytic products producing skin hemorrhage. J. Clin. Invest., 1954, 33, 1572.

4. Bliss, C. I., Statistical methods in vitamin research in Vitamin Methods. New York, Academic Press, 1951, vol. 2.

5. Glaubiger, A., The purification of diphtheria and tetanus antitoxin by the use of pepsin. J. Lab. \& Clin. Med., 1948, 33, 757.

6. Levine, L., Wyman, L., Chen, B. L., and Murphy, J., The quantitative determination of the extent of despeciation of modified equine antitoxin. J. Immunol., 1952, 69, 627.

7. Wadley, F. M., The use of biometric methods in comparison of acid-fast allergens. Am. Rev. Tuberc., 1949, 60, 131.

8. Swain, H. H., and Becker, E. L., Quantitative studies in skin testing: V. The whealing reactions of histamine and ragweed pollen extract. J. Allergy, 1952, 23, 441.

9. Menkin, V., Studies on inflammation. I. Fixation of vital dyes in inflamed areas. J. Exper. Med., 1929, 50, 171.

10. Bier, O., and Planet, N., Sur la perméabilité capillaire dans le phénomène de Shwartzman. Compt. rend. Soc. de biol., 1938, 129, 68.

11. Cullumbine, H., and Rydon, H. N., A study of the formation, properties, and partial purfication of leukotaxine. Brit. J. Exper. Path., 1946, 27, 33.
12. Hoppe, J. O., Alexander, E. B., and Miller, L. C., Use of the trypan blue and rabbit eye tests for irritation. J. Am. Pharm. A., 1950, 39, 147.

13. Rigdon, R. H., Capillary permeability in areas of inflammation produced by xylene. Arch. Surg., 1940, 41, 101.

14. Rocha E Silva, M., and Dragstedt, C. A., Observations on the trypan blue capillary permeability test in rabbits. J. Pharmacol. \& Exper. Therap., 1941, 73, 405.

15. Spector, W. G., The role of some higher peptides in inflammation. J. Path. \& Bact., 1951, 63, 93.

16. Tainter, M. L., Throndson, A. H., and Lehman, A. J., Local irritation from sodium bisulfite as preservative in epinephrine solutions. Proc. Soc. Exper. Biol. \& Med., 1937, 36, 584.

17. Duthie, E. S., and Chain, E., A polypeptide responsible for some of the phenomena of acute inflamation. Brit. J. Exper. Path., 1939, 20, 417.

18. Miles, A. A., and Miles, E. M., Vascular reactions to histamine, histamine-liberator and leukotaxine in the skin of guinea pigs. J. Physiol., 1952, 118, 228.

19. Moore, F. D., and Tobin, L. H., Studies with radioactive di-azo dyes. 1. The localization of radioactive di-brom trypan blue in inflammatory lesions. J. Clin. Invest., 1942, 21, 471. 